\title{
ANÁLISE DA PRODUÇÃO ACADÊMICA RELACIONADA À INCLUSÃO NOS ANAIS DIGITAIS DO ENCONTRO NACIONAL DE ENSINO DE QUÍMICA ENTRE 2014-2018
}

\author{
Anderson Rodrigues \\ Angela Sanches Rocha \\ Priscila Tamiasso-Martinhon
}

"O acesso à comunicação em seu sentido mais amplo é o acesso ao conhecimento, $e$ isso é de importância vital para nós, se não quisermos continuar sendo desvalorizados ou protegidos por pessoas videntes bondosas”. (Louis Braille)

\section{Introdução}

Em um país de dimensão continental, marcado tanto pela exclusão estrutural, quanto pelas especificidades e diversidade - culturais, étnicas, religiosas, econômicas, físicas, ideológicas, políticas - de sua população, é preciso que todos assumam responsabilidades para a construção de uma sociedade inclusiva e equalitária. Contudo, a realidade pontua que a vida de grande parte dos brasileiros ainda é caracterizada pelo preconceito, exclusão, carência de atendimento adequado em saúde e edu- 
cação, falta de acesso ao mundo do trabalho, do lazer, do esporte, da cultura, entre outros (TAMIASSOMARTINHON et al., 2018; PREUSSLER; CORDAZZO, 2018). Nesse contexto, enquanto o campo normativo tende a seguir mudanças paradigmáticas sobre como a sociedade compreende o processo de exclusão/inclusão, o campo operacional necessita se (re)articular para preencher as lacunas criadas pelas demandas não atendidas (BARRETO; REIS, 2011).

Apesar de controversas, pesquisas e indagações no campo da inclusão têm sido recorrentes em ensino, extensão e educação, advertindo sobre a necessidade de se ampliar o debate teórico-metodológico dessa temática, de modo a reduzir as fragilidades normativas e operacionais de seus domínios correlatos (BEYER, 2003; SAVIANI, 2011; AFONSO, 2013; SILVA; BEGO, 2018). Se por um lado, diferentes níveis multimodais podem ser empregados para esse tipo de investigação - sobretudo ao se considerar a interpenetração multidisciplinar que ela atinge e abrange - por outro, tais questionamentos nem sempre possuem respostas imediatas.

Uma maneira de expandir diálogos sobre teorias em aberto é participar de eventos científicos. Estes, por sua vez, cada vez mais se fortalecem como local de fala imprescindível ao incentivo de discussões, debates, reflexões, críticas, socialização e divulgação de conhecimento. É nesse ambiente de aprendizagem colaborativa, legiti- 
mação de pesquisas e de relatos de experiências, que temas de interesse no campo de atuação de sujeitos - discentes e docentes, tanto da Educação Básica (EB), quanto do Ensino Superior (ES); pesquisadores; extensionistas, profissionais liberais e da indústria - vinculados a diferentes áreas do conhecimento, se encontram dialogicamente (ou deveriam), sugerindo inclusive quais são as tendências mais recentes de investigação.

Ainda sobre eventos científicos, além do aspecto supracitado, eles são fundamentais durante o processo de apropriação da identidade discente docente aprendente de pesquisadores em formação. Logo, visitar e (re)visitar anais de eventos científicos, bem como estruturar revisões bibliográficas sistemáticas desses, podem contribuir para o surgimento de um olhar acadêmico mais amplo e consistente (LACERDA et al., 2008). Assim, o objetivo do presente trabalho consiste em compartilhar a análise realizada das publicações do Grupo de Trabalho (GT) Inclusão e Políticas Educacionais (IPE), disponibilizadas nos anais do Encontro Nacional de Ensino de Química (ENEQ), acessível nos portais eletrônicos das edições desse evento a partir de 2014.

\section{Considerações iniciais e referenciais teóricos}

O ENEQ é um dos principais congressos na área de Química do país, e, provavelmente, o maior e mais 
relevante encontro em Ensino de Química. Trata-se de um evento de extrema importância, que reúne pesquisadores de várias áreas e de diferentes campos de pesquisa (ENEQ, 2012/ 2014/ 2016/ 2018). A primeira edição, em 1982, foi realizada em Campinas (SP), na Faculdade de Educação da Universidade de Campinas (Unicamp). Desde então o evento ocorre bianualmente, contabilizando dezenove edições até o presente momento. Em 2020, a vigésima edição dessa reunião seria em Recife (PE). Contudo, devido ao isolamento social decorrente da pandemia de SARS-Cov2 (Covid-19) - declarada pela Organização Mundial de Saúde em março de 2020 - o XX ENEQ, que estava previsto para o mês de julho, acontecerá de forma remota em 2021, a fim de seguir as recomendações sanitárias vigentes. Portanto, não será considerada neste levantamento.

Em uma análise feita a partir dos Anais de 2010 do ENEQ ${ }^{1}$, foi possível identificar o surgimento de uma área específica destinada para temas relacionados a educação inclusiva. Este GT passou por algumas mudanças ao longo das últimas edições, até chegar ao formato atual - como ilustrado na Tabela 1 - e a partir de 2014 essa sessão passou a se chamar "Inclusão e Políticas Educacionais” (ENEQ, 2014/ 2016/ 2018), resultante da união do

\footnotetext{
${ }^{1}$ Os portais eletrônicos das edições anteriores ao ano de 2006 não estavam disponíveis durante a elaboração deste artigo.
} 
GT "Ensino de Química e Inclusão" com o GT "Políticas Educacionais e Educação Química” (ENEQ, 2012).

Tabela 1: Anos de realização do ENEQ constando as linhas temáticas voltadas para o tema "Inclusão"

\begin{tabular}{|c|c|}
\hline $\begin{array}{l}\text { Ano de Realiza- } \\
\text { ção do Evento }\end{array}$ & $\begin{array}{l}\text { Especificação da } \\
\text { Área Temática }\end{array}$ \\
\hline 2006 e 2008 & $\begin{array}{l}\text { Sem área temática es- } \\
\text { pecífica }\end{array}$ \\
\hline 2010 & Educação e Inclusão \\
\hline 2012 & $\begin{array}{l}\text { Ensino de Química e } \\
\text { Inclusão }\end{array}$ \\
\hline 2014 a 2018 & $\begin{array}{l}\text { Inclusão e Políticas } \\
\text { Educacionais }\end{array}$ \\
\hline
\end{tabular}

Fonte: Autoria própria, 2020.

O ENEQ vem embasando teoricamente vários trabalhos de cunho bibliográfico. Em geral esse tipo de levantamento, as vezes referido como estado da arte, é um estudo sistemático de revisão. Sua função é propiciar uma análise crítica sobre determinado tema, tendo como fonte de dados um recorte da literatura disponível, utilizando-se de métodos estruturados e definidos para angariar, agrupar e avaliar diversos estudos primários (VOSGERAU; ROMANOWSKI, 2014). Este tipo de pesquisa almeja mapear, em um período específico, a tendência de um determinado assunto científico, contribuindo para a disseminação de informações acadêmicas, além de confrontar dados e auxiliar profissionais na formulação de novas pesquisas (GALVÃO; PEREIRA, 2014; 
SAMPAIO; MANCINI, 2007; UNESP, 2015; OLIVEIRA, 2019).

Uma investigação metodológica passível de ser empregada em revisões bibliográficas é a Análise Textual Discursiva (ATD). Esta técnica permite que haja, dentro de desígnios previamente estabelecidos, a conciliação entre a objetividade da Análise de Conteúdo (AC), por intermédio de apreciações precedentes, inferência e interpretação dos dados, e a Análise do Discurso (AD) crítico, interpretativo e subjetivo das informações extraídas dos documentos, a partir de sua codificação (MORAES; GALIAZZI, 2007). Em outras palavras:

A ATD baseia-se na organização de argumentos em quatro focos básicos: 1) desmontagem de textos; 2) estabelecimento de relações; 3) captação do novo emergente e 4) um processo auto organizado. Os três primeiros eixos constituem um ciclo onde há a emergência de novas compreensões. Desta forma, a partir da imersão no processo de análise criam-se condições para atingir um processo auto organizado (quarto foco). A relação cíclica dos três primeiros focos de análise permite um exercício efetivo de aprender, um aprender auto organizado (FREITAS; QUEIRÓS, 2020, p. 328).

Ou seja, a ATD pode ser empregada como um método de análise qualitativa, intermediária entre a AC e a $\mathrm{AD}$, que permite reestruturar a compreensão sobre um 
objeto de estudo pela aproximação de elementos unitários. Esses elementos são denominados de unidades de sentido e juntam-se em grupos que compartilham alguma semelhança, resultando em uma categorização (MORAES, 2003). Durante ATD é muito comum o processo de identificação de descritores, que segundo Svenonius (2009) significa uma palavra/expressão capaz de sintetizar os pontos principais da produção textual que está sendo analisada. De forma geral, um descritor identifica ideias e temas importantes para servir de referência a pesquisas em bases de dados e mecanismo de buscas.

\section{Metodologia}

A pesquisa, classificada como qualitativadescritiva, utilizou como procedimento técnico o levantamento de Trabalhos Completos (TC) e Resumos Simples (RS), nos anais do ENEQ, na área categorizada pelo evento como IPE. A análise documental, de caráter exploratória e de natureza mista, foi realizada com base na proposta da ATD, aplicada aos títulos, palavras-chave e/ou resumos do material selecionado (MORAES; GALIAZZI, 2007). Para o escopo desse levantamento foi definido um período que compreendeu os encontros que ocorreram entre os anos de 2014 a 2018. Esse espaço de tempo corresponde às três últimas edições: Ouro Preto MG (ENEQ, 2014), Florianópolis - SC (ENEQ, 2016) e Rio Branco - AC (ENEQ, 2018). Esse recorte temporal 
levou em consideração o acesso às informações disponibilizadas no formato digital através dos respectivos portais eletrônicos. Um aspecto metodológico que precisa ser destacado é que a busca só foi realizada no GT IPE. Assim, trabalhos que poderiam ser enquadrados no campo da Educação Inclusiva, mas que foram submetidos por seus autores a outros GT (por exemplo "Formação de Professores"), não entraram no escopo deste trabalho.

Em um primeiro momento foi explorado o teor quantitativo do mapeamento textual, obtido a partir de buscas específicas, que chegaram a um quantitativo de 86 trabalhos. Na sequência foi feita uma triagem dos títulos, palavras-chave e resumos dos TC e RS, com intuito de verificar se o descritor presente no material selecionado pertencia ao campo pré-estabelecido para essa pesquisa, cujo recorte não incluiu análises sobre políticas educacionais. Essa etapa eliminou 14 publicações e a análise dos dados dos textos restantes estão disponíveis no APÊNDICE deste trabalho - Quadros A (ENEQ, 2014), B (ENEQ, 2016) e C (ENEQ, 2018). Após a leitura do material selecionado, iniciou-se a análise qualitativa dos textos, contextos, resultados e discussão de cada TC e RS.

A partir dos dados obtidos na etapa anterior, determinou-se as 5 categorias que seriam exploradas, que foram: i. Esfera de Ensino (EE), subdividida em EB (Fundamental I e II, e Ensino Médio) e ES (graduação e pós-graduação); ii. Formato de Apresentação (FA), indi- 
cando se o trabalho foi apresentado na modalidade TC ou RS; iii. Tipo de Produção (PRD), dividida em subcategorias (Quadro 1); iv. Alvo da Inclusão (AI), relativa ao recorte da inclusão (visual, auditiva, intelectual, gênero, racial, etc.); v. Local de Produção (UF), com o intuito de mapear a distribuição geográfica da pesquisa; vi. Instituições de Ensino (IE), indicando qual/quais instituições o(s) autor(es) estava(m) vinculado(s) no momento da elaboração do trabalho.

Quadro 1: Subcategorias vinculadas a categorização do Tipo de Produção (PRD) e suas respectivas definições

\begin{tabular}{|l|l|}
\hline PRD & \multicolumn{1}{c|}{ Definição } \\
\hline $\mathrm{MD}^{(1)}$ & $\begin{array}{l}\text { Atividades de elaboração de material específico } \\
\text { novo ou pré-existente para um determinado gru- } \\
\text { po. } \\
\text { Atividades voltadas para a formação de profissi- } \\
\text { onais da área. } \\
\text { Atividades de ação em algum grupo com uma } \\
\text { finalidade específica (diagnóstica, técnica, meto- } \\
\text { dológica, experimental, plano de ação). } \\
\text { Atividades de análise de um grupo visando sua } \\
\text { caracterização. } \\
\text { Atividades envolvendo análise de pesquisas so- } \\
\text { bre um tema específico dentro de uma área de } \\
\text { conhecimento. }\end{array}$ \\
$\mathrm{LB}^{(5)}$ & \\
$\mathrm{MD}^{(1)}=$ adaptação/produção de material didático; $\mathrm{FP}^{(2)}=$ formação
\end{tabular}

de professores; $\operatorname{IDP}^{(3)}=$ intervenção didático-pedagógica; $\mathrm{AP}^{(4)}=$ análise de perfil; $\mathrm{LB}^{(5)}=$ levantamento bibliográfico.

Fonte: Autoria própria, 2020. 
Cabe pontuar que a categorização que forneceu o mapeamento da distribuição geográfica de pesquisas no campo da inclusão, considerou apenas o local de origem do autor principal, sendo separado pelas regiões para facilitar a leitura dessas informações. Todas as análises se embasaram na ATD, que serão exploradas em resultados e discussão. A partir do levantamento e da análise do QPC chegou-se a um total de 212 descritores - presentes nos títulos, palavras-chave e/ou resumos. Estes foram reagrupados em 104 palavras e/ou expressões distintas, com o intuito de melhor caracterizar a distribuição dessas ideias nas três edições analisadas, que foram reagrupadas e apresentadas no Quadro 2.

Quadro 2: Categorização dos descritores presentes nas produções analisadas

\begin{tabular}{|c|c|c|}
\hline$>$ acessibilidade & $\begin{array}{l}>\text { formação profis- } \\
\text { sional }\end{array}$ & $\begin{array}{l}\text { metodologias, } \\
\text { didática e prá- } \\
\text { tica docente }\end{array}$ \\
\hline $\begin{array}{l}\text { área de conhe- } \\
\text { cimento* }^{*}\end{array}$ & $\begin{array}{l}\text { gênero, sexuali- } \\
\text { dade e represen- } \\
\text { tatividade }\end{array}$ & $\begin{array}{l}\text { organização do } \\
\text { ensino }\end{array}$ \\
\hline $\begin{array}{l}\text { conhecimentos } \\
\text { teóricos }\end{array}$ & $\begin{array}{l}\text { levantamento de } \\
\text { dados }\end{array}$ & $\begin{array}{l}\text { referenciais } \\
\text { teóricos }\end{array}$ \\
\hline$>$ especificidades $^{* *}$ & $\begin{array}{l}\text { leis, normas, } \\
\text { diretrizes e afins }\end{array}$ & $\begin{array}{l}\text { relações étni- } \\
\text { co-raciais }\end{array}$ \\
\hline $\begin{array}{l}\text { eventos, pro- } \\
\text { gramas, institui- } \\
\text { ções de pesquisa }\end{array}$ & $\begin{array}{l}\text { materiais e fer- } \\
\text { ramentas }\end{array}$ & $>$ tema gerador \\
\hline
\end{tabular}




\section{Resultados e Discussão}

A análise iniciada com 86 trabalhos (Quantitativo de Publicações Iniciais, QPI), após a primeira triagem foi reduzida a 72 (quantitativo de Publicações Categorizadas, QPC), como apresentado na Tabela 2. Os trabalhos que foram descartados não se relacionavam diretamente com educação inclusiva, pertencendo exclusivamente à área das políticas educacionais, e, apesar da relevância, a análise destes não foi prevista no desenho metodológico desse levantamento.

Tabela 2: Distribuição quantitativa referente ao número de publicações analisadas em cada edição do evento

\begin{tabular}{c|c|c|c}
\hline Edição (ENEQ) & Ano & QPI & QPC \\
\hline XVII & 2014 & 17 & 14 \\
XVIII & 2016 & 61 & 51 \\
XIX & 2018 & 8 & 7 \\
\hline \multicolumn{2}{r|}{ Total de publicações } & $\mathbf{8 6}$ & 72 \\
\hline
\end{tabular}

Fonte: Autoria própria, 2020.

A primeira categoria de análise mostra que tanto em 2014 quanto 2018 a maior quantidade de trabalhos foi voltada para o EB (figura 1). Contudo, não foi possível identificar em qual EE o RS intitulado "O homem trans e a química: análise do potencial das situações que atraves- 
sam esses sujeitos e suas experiências, para a abordagem de questões de gênero e sexualidade no ensino de química" (MARIN, 2018) poderia ser classificado pelos critérios estabelecidos na metodologia, uma vez que, apesar de embasar sua introdução nas Diretrizes Curriculares do Ensino Médio (BRASIL, 2012), sugere que o mesmo apresenta potencialidade de ser empregado durante o processo de formação do professor de química. Consequentemente, a EE desse RS transita entre a EB e o ES.

Ainda sobre a EE, no ano de 2016 verificou-se uma quantidade maior de trabalhos focados no ES, impulsionada pelas publicações relacionadas tanto ao Programa Institucional de Bolsas de Iniciação à Docência (PIBID) e ao campo de Formação Docente, quanto pelos trabalhos sobre o estado da arte de temáticas inclusivas e afins. Tomelin e colaboradores (2018) pontuam que a observação de práticas inclusivas no ES é um fenômeno recente, e que as instituições precisam ir além da simples disponibilidade da vaga específica por meio de cotas, executando ações, como redes de apoio e acompanhamento continuado. 
Figura 1: Resultados referentes à categoria Esfera de Ensino (EE)

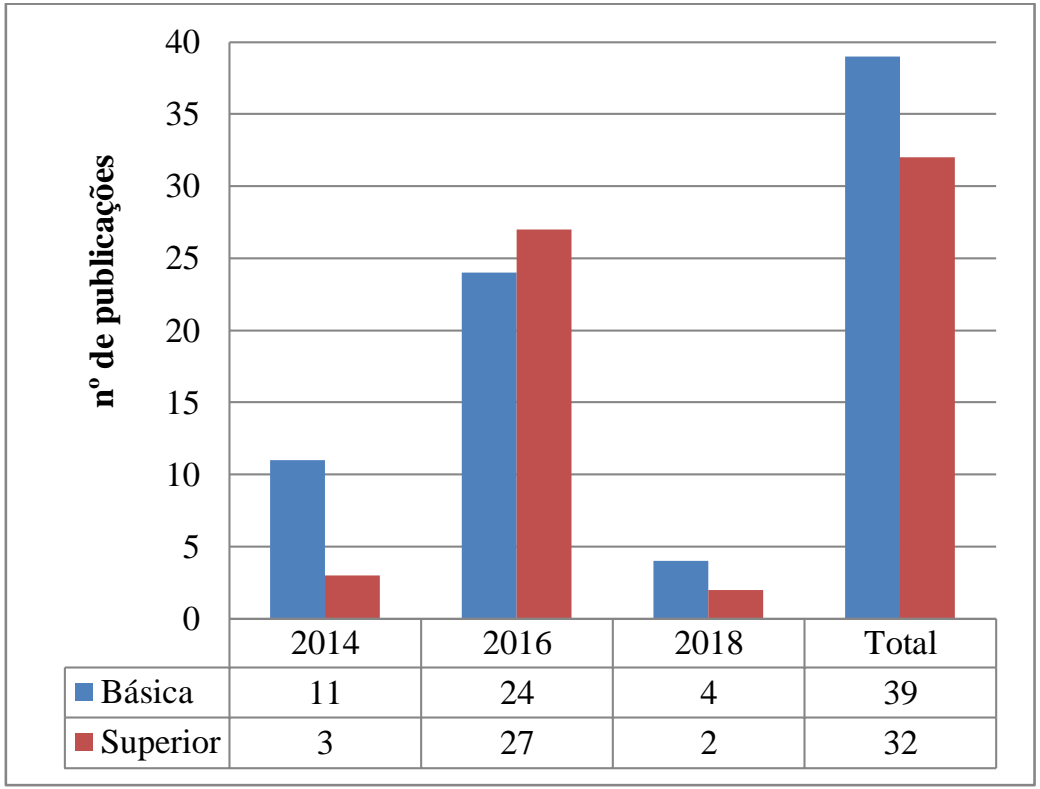

Fonte: Autoria própria, 2020.

A análise dos dados apresentados no Gráfico 1 corrobora com os resultados apresentados no último Censo Demográfico Brasileiro, realizado em 2010, em que foi evidenciado que 61,1 \% das pessoas com deficiência (PcD) no Brasil, maiores de 15 anos, não têm instrução ou têm o Ensino Fundamental incompleto. Outros 14,2 \% têm EF completo ou Ensino Médio (EM) incompleto, $17,7 \%$ têm EM completo ou ES incompleto, apenas 6,7 \% concluíram um curso superior e 0,3 \% não foram determinados (IBGE, 2010). Esse quantitativo chama mais 
atenção quando confrontado com os dados do Censo da Educação Superior, de 2018, em que dos 5.053 alunos matriculados, somente 165 concluíram o curso de graduação (INPE, 2018). Nos ENEQ analisados, a pósgraduação aparece como um terreno inexplorado para pesquisas sobre inclusão. Todavia, com a repercussão da revogação da portaria $n^{0} 545 / 16$ em junho deste ano, pelo ex-ministro da Educação Abraham Weintraub $(\mathrm{G} 1,2020)$, que desobriga as instituições de ensino superior a promoverem ações afirmativas para inclusão de minorias, espera-se que mais pesquisadores se dediquem ao problema futuramente.

Os resultados apresentados na figura 2 ilustram que a forma de apresentação mais comum foi TC, totalizando 42 trabalhos completos. Contudo, nos anais do XIX ENEQ (2018) não foram encontrados TC na área de IPE, provavelmente este quantitativo pode estar relacionado ao fato de que vários trabalhos apresentados no Acre foram selecionados para compor um dos três números da edição especial sobre o evento, na Revista Scientia Naturalis (2019). Hipótese confirmada pelos autores, que não incluíram esses artigos na análise, uma vez que o recorte foi específico para os trabalhos disponibilizados nos Anais. 
Figura 2: Resultados referentes à categoria Formato de Apresentação (FA)

\section{IResumoSimples ITrabaho Completo}

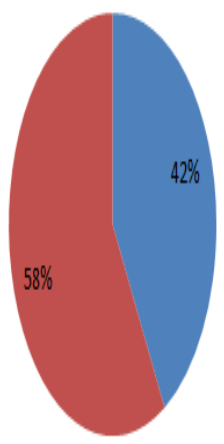

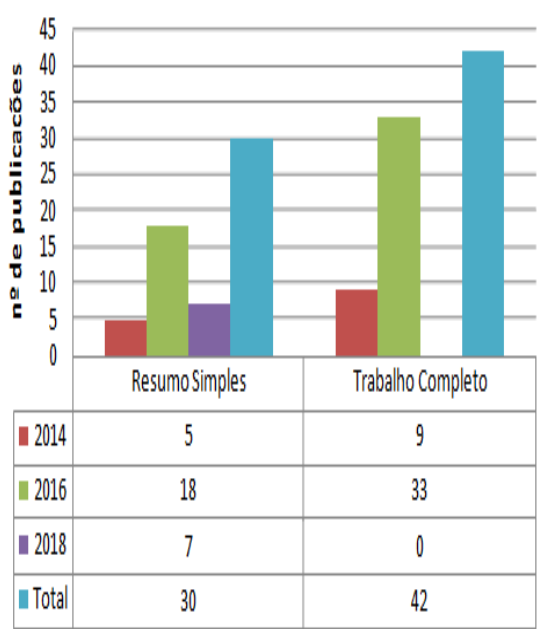

Fonte: Autoria própria, 2020.

A opção autoral pelo envio na modalidade TC permitiu uma compreensão mais ampla sobre a pesquisa, uma vez que as discussões realizadas foram mais profundas e elaboradas, colaborando para o desenvolvimento da área. Os resumos simples, por sua vez, estavam de modo geral relacionados a recortes de projetos maiores e/ou pesquisas em andamento, e foram apropriados para introduzir temáticas de uma maneira mais sucinta. Nos dois casos, o material analisado possui potencial para mediar reflexões críticas, e podem ser empregadas como 
ferramenta no processo de aprendizagem e apropriação de conteúdos relevantes para formação na área de IPE.

Evocando a concepção de que instituições de ensino - básico e/ou superior, público e/ou privado - devem propiciar um ambiente acolhedor de aprendizagem colaborativa para todos, independentemente de suas especificidades, seus Projetos Políticos Pedagógicos e Matrizes Curriculares precisam ser desenhados de modo que garantam oportunidades equalitárias, para que o corpo social da instituição cresça e avance coletivamente. Para isto, é necessário que a inclusão seja contemplada em vários aspectos, fazendo-se presente em todos os níveis e locais formais, ou não formais, de aprendizagem. Isso implica na aceitação e respeito às idiossincrasias, que enriquecem as vivências humanas, uma vez que seres sociais aprendem uns com os outros (FERRAZ, 2019).

Esses argumentos apareceram de forma explícita ou implícita nos trabalhos analisados, apesar de ainda haver assuntos que são pouco abordados em uma perspectiva inclusiva (MARIN, 2018; PEREIRA et al., 2018). A figura 3 denuncia essa fragilidade e mostra que o Tipo de Produção (PRD) mais recorrente foi a Intervenção Didático-Pedagógica (IDP), seguido por trabalhos sobre Formação Docente (FP), Adaptação/Produção de Materiais Didáticos (MD) e Levantamentos Bibliográficos (LB). 
Figura 3: Resultados referentes à categoria Tipo de Produção (PRD)

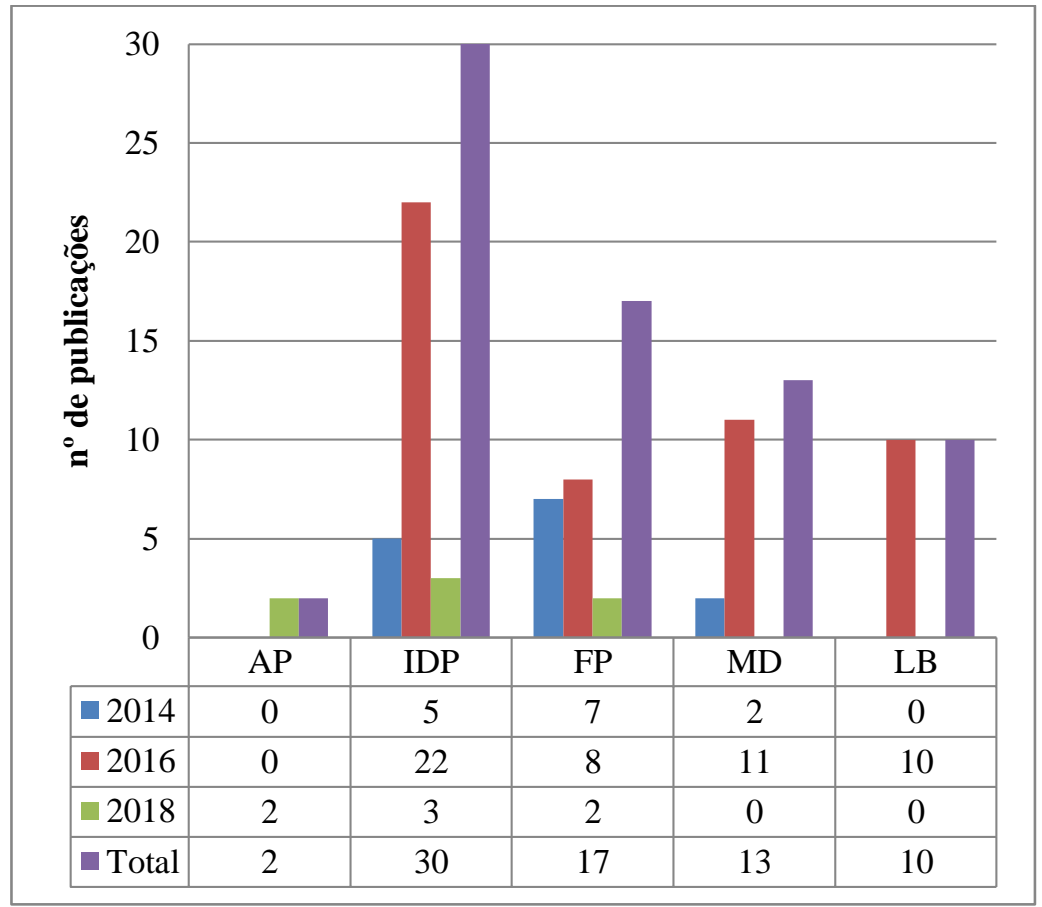

Fonte: autoria própria, 2020.

O PRD Análise de Perfil (AP) foi identificado apenas no evento de 2018, nos RS intitulados "O homem trans e a química: análise do potencial das situações que atravessam esses sujeitos e suas experiências, para a abordagem de questões de gênero e sexualidade no ensino de química" (MARIN, 2018) e "Perfil da representatividade de gênero em disciplinas de físico-química" (PEREIRA et al., 2018). Evidenciando a necessidade de se incentivar pesquisas nesse campo de saber. 
Com relação ao Quadro 3 a divisão de tópicos observada pela categorização dos descritores sugere uma estrutura comum: área de interesse, público-alvo e tema. Por exemplo, em "Ensino de química para surdos usando recursos didáticos inclusivos", a área de interesse seria o ensino de química, surdos o público alvo e o tema recursos didáticos inclusivos.

Quadro 3: Categorias e frequência (frq) dos descritores identificados nos textos analisados (entre parênteses se encontra a frq individual de cada entrada)

\begin{tabular}{|c|c|c|c|}
\hline \multicolumn{2}{|c|}{ Categoria } & Frq & Descritores \\
\hline \multirow{2}{|c|}{ Acessibilidade } & 3 & $\begin{array}{c}\text { no ensino superior (1); acesso à } \\
\text { ciência (1); adaptação de recur- } \\
\text { sos (1) }\end{array}$ \\
\hline \multirow{2}{*}{$\begin{array}{c}\text { Área de Co- } \\
\text { nhecimento }\end{array}$} & (a) Geral & 28 & $\begin{array}{c}\text { inclusão (11); química (10); } \\
\text { aprendizagem (2); ensino (2); } \\
\text { educação (1); ensino e aprendi- } \\
\text { zagem (1), inclusão e química } \\
\text { (b) Específica }\end{array}$ \\
\cline { 2 - 4 } & 52 & $\begin{array}{c}\text { ensino de química (32); educa- } \\
\text { ção inclusiva (11); inclusão } \\
\text { escolar (3); educação especial } \\
\text { (2); ensino especial (2); educa- } \\
\text { ção química (1); ensino de } \\
\text { ciências (1) }\end{array}$ \\
\cline { 2 - 4 } & (c) Aplicada & 5 & $\begin{array}{c}\text { aula de química (1); educação } \\
\text { de surdos (4) }\end{array}$ \\
\hline \multirow{2}{*}{ Conhecimentos Teóricos } & 8 & $\begin{array}{c}\text { tabela periódica (2); ácidos e } \\
\text { bases de Arrhenius (1); concei- } \\
\text { tos químicos (1); transformação } \\
\text { química (1); transformações }\end{array}$ \\
\hline
\end{tabular}




\begin{tabular}{|c|c|c|c|}
\hline & & & $\begin{array}{c}\text { (1); representação imagética } \\
\text { (1); semiótica (1) }\end{array}$ \\
\hline \multirow{4}{*}{ Especificidades } & (a) Genérica & 4 & $\begin{array}{l}\text { pessoa com deficiência (2); } \\
\text { aluno com deficiência (1); } \\
\text { deficiência (1) }\end{array}$ \\
\hline & (b) Visual & 12 & $\begin{array}{c}\text { deficiência visual (7); cego (1); } \\
\text { cegos (1); cegueira (1); docente } \\
\text { cego (1); sensibilidade cromá- } \\
\text { tica (1) }\end{array}$ \\
\hline & $\begin{array}{l}\text { (c) Intelectual; } \\
\text { Cognitiva }\end{array}$ & 4 & $\begin{array}{c}\text { síndrome de down (2); altas } \\
\text { habilidades/super dotação (1); } \\
\text { autismo (1) }\end{array}$ \\
\hline & (d) Auditiva & 23 & $\begin{array}{l}\text { surdo (6); surdez (4); surdos } \\
\text { (2); alunos surdos (1); estudan- } \\
\text { tes ouvintes (1); estudantes } \\
\text { surdos (1); libras (6); sinais (1); } \\
\text { sign writting (1) }\end{array}$ \\
\hline \multicolumn{2}{|c|}{$\begin{array}{l}\text { Eventos, Programas e Institui- } \\
\text { ções de Pesquisa }\end{array}$} & 8 & $\begin{array}{l}\text { PIBID (2); } \text { APAE* (1); ENEQ }^{*} \\
\text { (1); escola pública (1); grupos } \\
\text { de pesquisa (1); rede de apoio } \\
\text { (1); SEI** (1) }\end{array}$ \\
\hline \multicolumn{2}{|c|}{ Formação Profissional } & 10 & $\begin{array}{l}\text { formação de professores (5); } \\
\text { formação (1); formação docen- } \\
\text { te (1); formação docente em } \\
\text { química (1); necessidades for- } \\
\text { mativas (1); professores (1) }\end{array}$ \\
\hline \multicolumn{2}{|c|}{$\begin{array}{l}\text { Gênero, Sexualidade e Represen- } \\
\text { tatividade }\end{array}$} & 8 & $\begin{array}{c}\text { gênero (2); educação sexual } \\
\text { (1); equidade de gênero (1); } \\
\text { química da sexualidade (1); } \\
\text { sexualidade (1); representativi- } \\
\text { dade (1) }\end{array}$ \\
\hline \multicolumn{2}{|c|}{ Levantamento de Dados } & 3 & $\begin{array}{l}\text { estado da arte (1); produção } \\
\text { acadêmica (1); triangulação (1) }\end{array}$ \\
\hline
\end{tabular}




\begin{tabular}{|c|c|c|}
\hline Leis, Normas, Diretrizes e Afins & 7 & Lei 10.639/03 (7) \\
\hline Materiais e Ferramentas & 9 & $\begin{array}{l}\text { materiais didáticos (3); recurso } \\
\text { didático inclusivo (2); artefatos } \\
\text { químicos (1); audiodescrição } \\
\text { (1); recursos alternativos (1); } \\
\text { tecnologia assistiva (1) }\end{array}$ \\
\hline $\begin{array}{c}\text { Metodologias, Didática e Prática } \\
\text { Docente }\end{array}$ & 12 & $\begin{array}{l}\text { experimentação (2); atividades } \\
\text { inclusivas (1); didática (1); } \\
\text { estratégia didática (1); experi- } \\
\text { mentos (1); experimentos de } \\
\text { química (1); interações (1); } \\
\text { mediação (1); mediação do } \\
\text { conhecimento científico (1); } \\
\text { metodologia de ensino (1); } \\
\text { raciocínio qualitativo (1) }\end{array}$ \\
\hline Organização do Ensino & 2 & currículo (1), disciplinas (1) \\
\hline Referenciais Teóricos & 2 & Bachelard (1); Foucault (1) \\
\hline Relações Étnico-Raciais & 4 & $\begin{array}{c}\text { cultura africana (1), descoloni- } \\
\text { zação do currículo (1), diáspora } \\
\text { (1), diáspora africana no Brasil } \\
\text { (1) }\end{array}$ \\
\hline Tema Gerador & 8 & $\begin{array}{l}\text { aquecimento global (1); café } \\
\text { (1); extração de cafeína (1); } \\
\text { mulheres na ciência (1); platina } \\
\text { (1); política (1); proteção da } \\
\text { pele (1); reciclagem (1) }\end{array}$ \\
\hline
\end{tabular}

${ }^{*} \mathrm{APAE}=$ Associação de Pais e Amigos dos Excepcionais $;{ }^{* *} \mathrm{SEI}=\mathrm{Se}-$ quência de Ensino Investigativa.

Fonte: Autoria própria, 2020.

Ao se comparar a categorização dos descritores com a frequência que estes aparecem nos textos (Quadro 
3) nota-se que 63 trabalhos direcionaram o debate sobre inclusão para um público alvo específico (Figura 4) sendo mais comuns os trabalhos que se destinavam a $\mathrm{PcD}$, mais precisamente alunos com deficiência visual (24\%) e auditiva (41\%). Merece destaque a ocorrência de outros campos de inclusão - como racial, de gênero e sexualidade que são assuntos raramente designados à área da Educação Inclusiva no Ensino de Química. Curiosamente não houve registro de trabalho algum que se dedicasse à inclusão de alunos com algum tipo de deficiência motora.

Figura 4: Resultados referentes à categoria Alvo da Inclusão (AI)

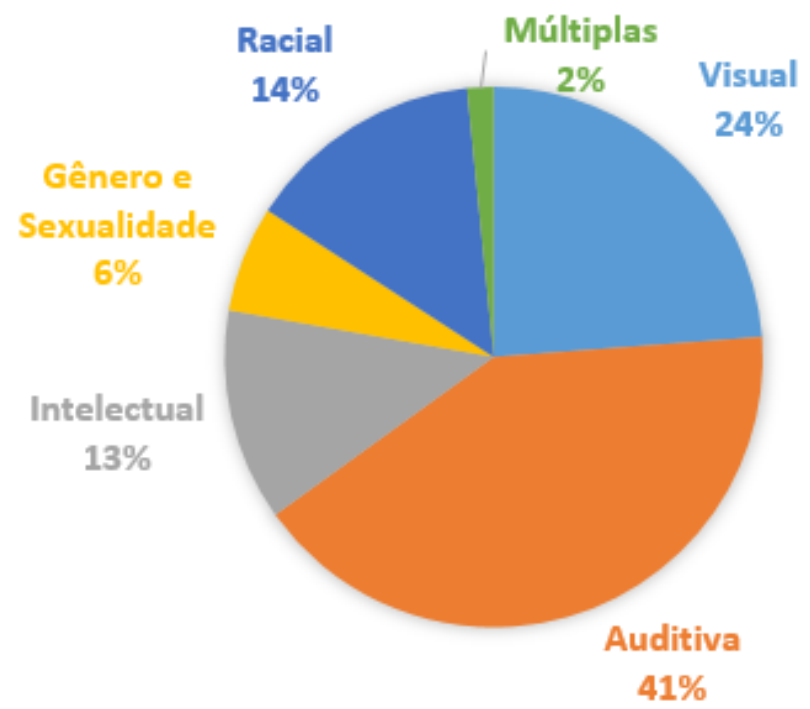

Fonte: Autoria própria, 2020. 
Levando em consideração que a Educação Inclusiva surgiu de um movimento social que tinha por objetivo romper com o paradigma da exclusão de minorias, que eram marginalizadas no processo educacional (CAPELLINI; MENDES, 1995), a inserção de grupos, que antes eram "invisíveis", sugere que as discussões sobre inclusão no Ensino de Química podem ser expandidas para lugares inexplorados e com bastante potencial de pesquisa.

Os dados referentes ao local de produção dos trabalhos (Figura 5) apontam uma concentração dos trabalhos (88\%) na região centro-sul do país. A região centrooeste foi a região com maior número de publicações (28) com Goiás liderando com 19 trabalhos. Correlacionando o vínculo dos autores com alguma instituição de pesquisa, contabilizaram-se 46 locais distribuídos entre universidades, institutos federais, centros de pesquisa e instituições de ensino básico. Entre estudantes de iniciação científica (IC), pesquisadores, professores, pós-graduandos e etc., chama a atenção o número de vínculos com alguma instituição do estado de Goiás, que corresponde a $26 \%$ do total, sendo a Universidade Federal de Goiás (UFG) responsável por impressionantes 16\% de participações (Gráfico 5). 
Figura 5: Resultados referentes à categoria Local de Produção (UF) e Instituições de Ensino (IE)
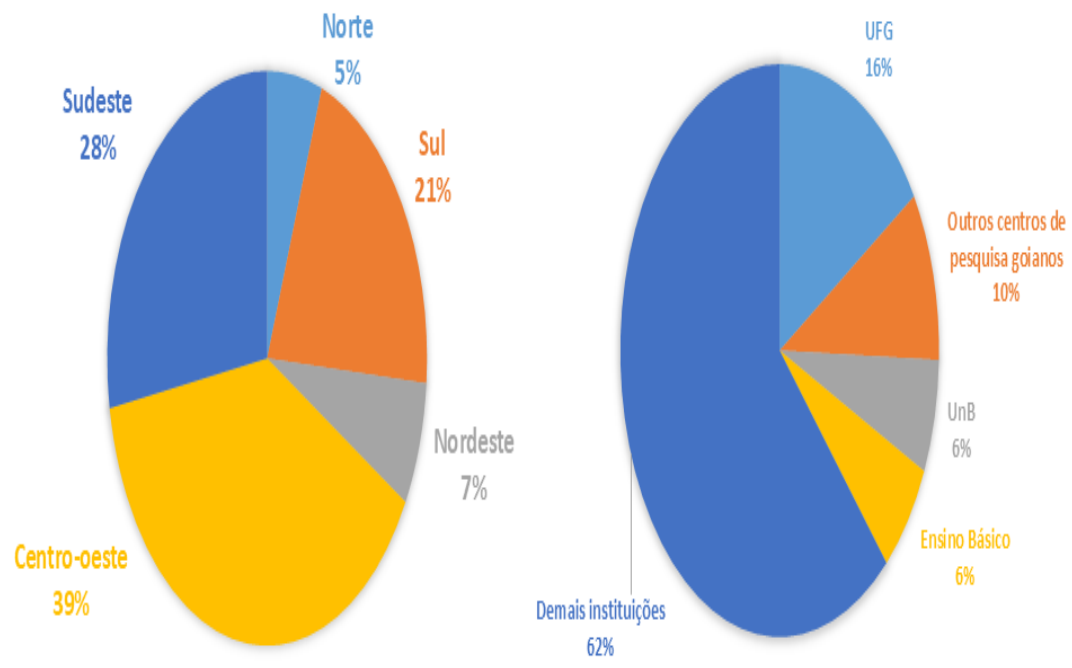

Fonte: autoria própria, 2020.

Esse dado é explicado pela forte ação de grupos de pesquisa em Ensino Inclusivo da UFG e em outros centros do estado - tais como o Instituto Federal de Goiás (IFG) e o Instituto Federal Goiano (IF Goiano) - com destaque especial ao Centro de Ensino e Pesquisa Aplicada à Educação (CEPAE), ao Laboratório de Pesquisa em Educação Química e Inclusão (LPEQI) e ao Coletivo Ciata, vinculado ao LPEQI. Schuindt e Matos (2016), obtendo um resultado semelhante entre 2008 e 2014, relacionaram o número de publicações com o surgimento de Grupos de Pesquisa dedicados ao tema para suprir a de- 
manda regional de capacitação profissional, e ao que tudo indica, a demanda persistiu no período avaliado.

Outro dado que chamou atenção foi a quantidade de trabalhos que contaram com participação de pesquisadores de instituições de pesquisa diferentes. Do quantitativo analisado, verificou-se que 13 dos 72 trabalhos analisados (18\%) envolviam duas ou mais instituições. Os autores consideram que este dado pode ser visto como um estímulo ou um convite a uma maior colaboração entre pares, suscitando o intercâmbio de ideias e experiências oriundas de diversos locais, a fim de enriquecer os debates e as produções acadêmicas relacionadas.

Apesar de a região sudeste aparecer como a segunda região em termos de produção (totalizando 20 publicações no conjunto analisado), o Rio de Janeiro, local de origem dos autores deste trabalho e, portanto, de interesse para o grupo de pesquisa, foi responsável apenas por três trabalhos o que representa somente $4 \%$ do total de publicações avaliadas.

Ao se pesquisar na Plataforma Lattes por grupos de pesquisa em "Inclusão no Ensino de Química" registrados no estado, obtivemos dois resultados: Laboratório de Química de Materiais Avançados (LQMA) na linha de pesquisa "Inclusão Social" e o Grupo de Pesquisa em Experimentação no Ensino de Química, ambos da Universidade Federal do Rio de Janeiro (UFRJ). Essa informação 
sugere que a participação dos profissionais e estudantes dos cursos de licenciatura e pós-graduação pode e deve ser mais incentivada na maioria dos estados brasileiros, incluindo o Rio de Janeiro, atraindo mais alunos dos cursos citados a participar desses eventos e de grupos de pesquisa assim como ocorrido no estado de Goiás, a fim de ampliar a adesão de pesquisadores.

\section{Considerações finais}

Esta técnica (ATD) permitiu que dentro dos objetivos estabelecidos houvesse a conciliação entre a objetividade (por meio de pré-análise, inferência e interpretação dos dados, típico da AC) com uma análise crítica, interpretativa e subjetiva das informações extraídas dos documentos a partir de sua codificação e categorização.

Com relação aos resultados, a primeira consideração a ser feita a partir dos dados recolhidos é o número relativamente pequeno de trabalhos dentro da linha temática que é destinada para o assunto, haja visto que apenas na edição de 2016 foram 1602 trabalhos submeti$\operatorname{dos}^{2}$. Ou seja, o número de trabalhos dentro da linha temática da inclusão representou apenas $0,04 \%$ do total para aquele ano e, mesmo se considerarmos publicações

${ }^{2} \mathrm{O}$ site da edição de 2016 foi o único que a informação sobre a totalidade dos trabalhos foi divulgada. 
que também abordam a inclusão, porém não se encaixaram dentro do recorte desse trabalho, a expectativa seria aquém do desejado para representar uma mudança do panorama da inclusão efetiva, no que tange à educação brasileira.

Foi constatado um grande volume de trabalhos nessa área direcionados para ações de intervenção ou adaptação de material didático, particularmente para estudantes que apresentam algum tipo de especificidade visual ou auditiva, evidenciado pela frequência de palavras-chave relacionadas com o assunto. Ao mesmo tempo um dado interessante que emergiu da análise foi a presença de publicações que levem em consideração a inclusão baseada em gênero e sexualidade, e também racial, ampliando o leque de discussões que a Educação Inclusiva pode fornecer, ao englobar também outros grupos em situação de fragilidade social.

A perspectiva para a próxima edição é que mais trabalhos desse tipo sejam produzidos e espera-se que a linha temática dedicada ao assunto - nomeada "Diversidade e Inclusão" - tenha um crescimento significativo no volume de publicações em relação às edições anteriores. É importante destacar o trabalho de grupos de estudos localizados majoritariamente nas regiões Sul, Sudeste e Centro-Oeste, que impulsionam a produção e desempenham papel de destaque nesse campo do conhecimento. Os autores desse levantamento esperam que as contribui- 
ções e discussões aqui apresentadas sirvam de base para futuros conhecimentos a serem produzidos dentro do campo da Educação Inclusiva, bem como suscitem reflexões sobre o tema.

\section{Referências}

AFONSO, D. Os desafios da educação inclusiva: foco nas redes de apoio. Revista Nova Escola, 2013.

BARRETO, C. S. G; REIS, M. B. F. Educação inclusiva: do paradigma da igualdade para o paradigma da diversidade. Revista Polyphonía, v. 22, n. 1, p. 19-32, 2011.

BEYER, H. O. A educação inclusiva: incompletudes escolares e perspectivas de ação. Revista Educação Especial, v. 1, n. 1, p. 33-44, 2003.

BRASIL. Conselho Nacional de Educação. Câmara da Educação Básica. Diretrizes Curriculares Nacionais para o Ensino Médio. Resolução CNE/CEB $n^{\circ}$ 2. Brasília, 2012. Disponível em:

$<$ http://portal.mec.gov.br/index.php?option=com_docman\&v iew=download\&alias=9917-rcebo02-12-1\&Itemid=30192 > .

Acesso em: 3 nov. 2020.

CAPELLINI, V. L. M. F.; MENDES, E. G. História da Educação Especial: em busca de um espaço na história da educação brasileira. UNESP/Bauru, 1995.

ENEQ. Encontro Nacional de Ensino de Química, XVI., 2012, Salvador - BA. Anais [...]. Salvador: Sociedade Brasileira de Química, 2012. Disponível em: 
<https://periodicos.ufba.br/index.php/anaiseneq2012/index> . Acesso em: 04 ago. 2020.

ENEQ. Encontro Nacional de Ensino de Química, XVII., 2014, Ouro Preto - MG. Anais [...]. Ouro Preto: Sociedade Brasileira de Química, 2014. 5528 p. Disponível em: $<$ http://www.sbq.org.br/eneq/xvii/anais_xvii_eneq.pdf > . Acesso em: 04 ago. 2020.

ENEQ. Encontro Nacional de Ensino de Química, XVIII., 2016, Florianópolis - SC. Anais [...]. Florianópolis: Sociedade Brasileira de Química, 2016. Disponível em: <http://www.eneq2016.ufsc.br/index.php/component/k2/ite $\mathrm{m} / 101$-certificados/101-certificados $>$. Acesso em: 04 ago. 2020.

ENEQ. Encontro Nacional de Ensino de Química, XIX., 2018, Rio Branco - AC. Anais [...]. Rio Branco: Sociedade Brasileira de Química, 2018. 2033 p. Disponível em: <http://www.eneq2018noacre.com.br/conteudo/view?ID_CO NTEUDO=421>. Acessado em: 04 ago. 2020.

FERRAZ, D. M. Visibilidade LGBTQIA+ e Educação Linguística: por entre os discursos de ódio, aceitação e respeito. Revista $X$, v. 14, n. 4, p. 200-221, 2019.

G1. MEC revoga portaria que acabava com incentivo a cotas para negros, indígenas e pessoas com deficiência na pósgraduação. Disponível em: <https://g1.globo.com/educacao/noticia/2020/o6/23/mecrevoga-portaria-que-acabava-com-incentivo-a-cotas-paranegros-indigenas-e-pessoas-com-deficiencia-na-posgraduacao.ghtml>. Acesso em: 06 ago. 2020.

FREITAS, W. P. S.; QUEIRÓS, W. P. O processo de compreensão das interações Ciência-Tecnologia-Sociedade (CTS) em um 
curso de formação inicial de professores de física. Experiências em Ensino de Ciências, v. 15, n. 2, p. 324-347, 2020.

GALVÃO, T. F.; PEREIRA, M. G. Revisões sistemáticas da literatura: passos para sua elaboração. Epidemiologia e Serviços de Saúde, v. 23, p. 183-184, 2014.

IBGE. Instituto Brasileiro de Geografia e Estatística. Censo de $2010 . \quad$ Disponível em: <http://www.ibge.gov.br/home/estatistica/populacao/censo2 010/default.shtm>. Acesso em: 05 ago. 2019.

INEP. Instituto Nacional de Estudos e Pesquisas Educacionais Anísio Teixeira. Sinopse Estatística da Educação Superior 2018. Brasília: Inep, 2019. Disponível em: $<$ http://inep.gov.br/sinopses-estatisticas-da-educacaosuperior $>$. Acessado em: 24 ago. 2019.

LACERDA, A. L.; WERBER, C.; PORTO, M. P.; SILVA, R. A. A importância dos eventos científicos na formação acadêmica: estudantes de biblioteconomia. Revista ACB: Biblioteconomia em Santa Catarina, v. 13, n. 1, p. 130-144, 2008.

MARIN, Y. A. O. O homem trans e a química: análise do potencial das situações que atravessam esses sujeitos e suas experiências, para a abordagem de questões de gênero e sexualidade no ensino de química. In: ENCONTRO NACIONAL DE ENSINO DE QUÍMICA, XIX., 2018, Rio Branco - AC. Anais [...]. Rio Branco: Sociedade Brasileira de Química, 2018.

MORAES, R. Uma tempestade de luz: a compreensão possibilitada pela análise textual discursiva. Revista Ciência \& Educação, v. 9, n. 2, p. 191-211, 2003.

MORAES, R.; GALIAZZI, M. C. Análise textual discursiva. Ijuí: Editora Unijuí, 2007. 
OLIVEIRA, J. Análise da produção científica com a temática inclusão no ensino superior: reflexões sobre artigos publicados no período de 2016 a novembro de 2018. Revista Educação Especial, v. 32, p. 1-27, 2019.

PEREIRA, C. F.; GERPE, R. L.; ROCHA, A. S.; SOUSA, C.; BECKER, S.; TAMIASSO-MARTINHON, P. Perfil da representatividade de gênero em disciplinas de físico-química. In: ENCONTRO NACIONAL DE ENSINO DE QUÍMICA, XIX., 2018, Rio Branco - AC. Anais [...]. Rio Branco: Sociedade Brasileira de Química, 2018.

PREUSSLER, G. S.; CORDAZZO, K. Resenha - A sociedade excludente: exclusão social, criminalidade e diferença na modernidade recente (Jock Young). Revista Direito \& Práxis, v. 9, n. 1, p. 563-576, 2018.

SAMPAIO, R. F.; MANCINI, M. C. Estudos de revisão sistemática: um guia para síntese criteriosa da evidência científica. Revista Brasileira de Fisioterapia, v. 11, n. 1, p. 83-89, 2007.

SAVIANI, D. Sobre a natureza e a especificidade da educação. In: Saviani, D. (org.). Pedagogia histórico-crítica: primeiras aproximações. 10 ${ }^{\mathrm{a}}$ ed., São Paulo: Autores Associados, 2011. p. 11-20.

SCHUINDT, C. C.; MATOS, C. F.; SILVA, C. S. Os caminhos da Educação Inclusiva para o Ensino de Química: uma análise dos anais dos Encontros Nacionais de Ensino de Química, de 2008 a 2014. In: ENCONTRO NACIONAL DE ENSINO DE QUÍMICA, XVIII., 2016, Florianópolis - SC. Anais [...]. Florianópolis: Sociedade Brasileira de Química, 2016.

SILVA, L. V.; BEGO, A. M. Levantamento bibliográfico sobre educação especial e ensino de ciências no Brasil. Revista Brasileira de Educação Especial, v. 24, n. 3, p. 343-358, 2018. 
SVENONIUS, E. The intellectual foundation of information organization. Cambridge: MIT Press, 2009. 255p.

TAMIASSO-MARTINHON, P.; QUITETE, T. M. S.; ROCHA, A. S. R.; SOUSA, C. Um olhar discente-docente sobre a inclusão nas grades curriculares. In: COLÓQUIO INTERNACIONAL EDUCAÇÃO, CIDADANIA E EXCLUSÃO, V., 2018, Niterói. Anais [...]. Niterói: V CEDUCE, Universidade Federal Fluminense, Niterói, 2018.

TOMELIN, K. N.; DIAS, A. P. L.; SANCHEZ, C. N. M.; PERES, J.; CARVALHO, S. Educação inclusiva no ensino superior: desafios e experiências de um núcleo de apoio discente e docente. Revista Psicopedagogia, v. 35, n. 106, p. 94-103, 2018.

UNESP. Universidade Estadual Paulista. Tipos de Revisão de Literatura. Campus Botucatu. Faculdade de ciências agronômicas. Biblioteca Paulo de Carvalho Mattos. 2015. Disponível em: $\quad<$ http://www.fca.unesp.br/Home/Biblioteca/tipos-deevisao-de-literatura.pdf $>$. Acesso em: 20 jun. 2020.

VOSGERAU, D. S. R.; ROMANOWSKI, J. P. Estudos de revisão: implicações conceituais e metodológicas. Revista Diálogo Educacional, v. 14, n. 41, p. 165-189, 2014.

\section{Apêndice}

Quadro A - Publicações avaliadas dos anais digitais disponibilizados pelo XVII ENEQ (2014)

\begin{tabular}{|c|c|c|c|c|c|c|}
\hline Título & $\begin{array}{c}\text { Palavras- } \\
\text { chave }\end{array}$ & EE & PRD & AI & FA & IE \\
\hline $\begin{array}{c}\text { Análise da acessibili- } \\
\text { dade do Instituto de } \\
\text { Química/UFRGS: a }\end{array}$ & $\begin{array}{c}\text { Acessibilidade } \\
\text { no Ensino Supe- } \\
\text { rior, Inclusão, }\end{array}$ & ES & FP & - & TC & UFRGS \\
\hline
\end{tabular}




\begin{tabular}{|c|c|c|c|c|c|c|}
\hline $\begin{array}{l}\text { inclusão no ensino } \\
\text { superior em foco }\end{array}$ & $\begin{array}{l}\text { Pessoa com } \\
\text { deficiência }\end{array}$ & & & & & \\
\hline $\begin{array}{l}\text { As contribuições dos } \\
\text { recursos visuais no } \\
\text { ensino de química na } \\
\text { perspectiva da edu- } \\
\text { cação inclusiva no } \\
\text { contexto da surdez } \\
\text { usando o tema auto- } \\
\text { medicação }\end{array}$ & $\begin{array}{l}\text { Ensino de quími- } \\
\text { ca; Inclusão; } \\
\text { Surdos }\end{array}$ & EB & MD & $\begin{array}{l}\text { Auditi- } \\
\text { va }\end{array}$ & TC & $\begin{array}{c}\text { FURB, } \\
\text { EEAO } \\
\text { A }\end{array}$ \\
\hline $\begin{array}{l}\text { Diagnóstico das } \\
\text { dificuldades enfren- } \\
\text { tadas por professores } \\
\text { de Química para o } \\
\text { trabalho com a edu- } \\
\text { cação inclusiva no } \\
\text { Município de Cam- } \\
\text { pina Grande - PB. }\end{array}$ & $\begin{array}{l}\text { Formação de } \\
\text { professores, } \\
\text { Educação Inclu- } \\
\text { siva, Ensino de } \\
\text { Química }\end{array}$ & EB & FP & - & $\mathrm{RS}$ & UEPB \\
\hline $\begin{array}{l}\text { Ensino de Química e } \\
\text { a Ciência de Matriz } \\
\text { Africana: Uma Dis- } \\
\text { cussão Sobre as } \\
\text { Propriedades dos } \\
\text { Metais }\end{array}$ & $\begin{array}{l}\text { Ensino de quími- } \\
\text { ca, Lei 10.639- } \\
\text { 03, diáspora } \\
\text { africana no } \\
\text { Brasil }\end{array}$ & EB & IDP & Racial & $\mathrm{TC}$ & UFG \\
\hline $\begin{array}{l}\text { Formação continuada } \\
\text { de professores de } \\
\text { ciências para a edu- } \\
\text { cação inclusiva: } \\
\text { identificando suas } \\
\text { necessidades forma- } \\
\text { tivas }\end{array}$ & $\begin{array}{l}\text { Formação de } \\
\text { Professores, } \\
\text { Educação Inclu- } \\
\text { siva, Necessida- } \\
\text { des Formativas }\end{array}$ & EB & FP & - & $\mathrm{TC}$ & UESC \\
\hline $\begin{array}{l}\text { Inclusão Escolar e } \\
\text { Ensino de Ciências: o } \\
\text { estado da arte no } \\
\text { Brasil e na Universi- } \\
\text { dade de Brasília }\end{array}$ & $\begin{array}{l}\text { Inclusão escolar, } \\
\text { Ensino Especial. }\end{array}$ & ES & FP & - & $\mathrm{RS}$ & UnB \\
\hline $\begin{array}{l}\text { Investigação sobre } \\
\text { ensino para alunos } \\
\text { com deficiência } \\
\text { cognitiva: proposta }\end{array}$ & $\begin{array}{c}\text { Deficiência, } \\
\text { Inclusão, Quími- } \\
\text { ca }\end{array}$ & EB & IDP & $\begin{array}{l}\text { Intelec- } \\
\text { tual }\end{array}$ & TC & IFES \\
\hline
\end{tabular}




\begin{tabular}{|c|c|c|c|c|c|c|}
\hline $\begin{array}{c}\text { de atividade didática } \\
\text { para ensino de quí- } \\
\text { mica. }\end{array}$ & & & & & & \\
\hline $\begin{array}{l}\text { Mediação do conhe- } \\
\text { cimento científico } \\
\text { articulada pelo pro- } \\
\text { fessor durante uma } \\
\text { aula sobre Transfor- } \\
\text { mações Químicas } \\
\text { para estudantes } \\
\text { surdos }\end{array}$ & $\begin{array}{c}\text { Educação dos } \\
\text { Surdos, Media- } \\
\text { ção do conheci- } \\
\text { mento científico, } \\
\text { Transformações } \\
\text { Químicas }\end{array}$ & EB & IDP & $\begin{array}{l}\text { Auditi- } \\
\text { va }\end{array}$ & RS & UFV \\
\hline $\begin{array}{l}\text { O Ensino de Química } \\
\text { e o Sujeito Surdo: a } \\
\text { Linguagem e a Esco- } \\
\text { la e sua Relação com } \\
\text { Michael Foucault. }\end{array}$ & $\begin{array}{c}\text { Surdo, Foucault, } \\
\text { química. }\end{array}$ & EB & FP & $\begin{array}{c}\text { Auditi- } \\
\text { va }\end{array}$ & RS & $\begin{array}{l}\text { UFJF, } \\
\text { UFV }\end{array}$ \\
\hline $\begin{array}{l}\text { O ensino de química } \\
\text { para alunos surdos: } \\
\text { Um estudo de caso } \\
\text { no município de São } \\
\text { Mateus-ES. }\end{array}$ & $\begin{array}{c}\text { Química, libras, } \\
\text { ensino. }\end{array}$ & EB & IDP & $\begin{array}{c}\text { Auditi- } \\
\text { va }\end{array}$ & $\mathrm{TC}$ & UFES \\
\hline $\begin{array}{l}\text { O professor de Quí- } \\
\text { mica e a deficiência } \\
\text { visual. }\end{array}$ & $\begin{array}{l}\text { Química, Ce- } \\
\text { gueira, Inclusão }\end{array}$ & EB & FP & Visual & RS & UFAC \\
\hline $\begin{array}{l}\text { Recurso didático } \\
\text { inclusivo para medi- } \\
\text { ação dos conceitos de } \\
\text { ácido e base de } \\
\text { arrhenius }\end{array}$ & $\begin{array}{l}\text { Recurso didático } \\
\text { inclusivo, Defi- } \\
\text { ciência visual, } \\
\text { Ácidos e bases } \\
\text { de Arrhenius. }\end{array}$ & EB & MD & Visual & $\mathrm{TC}$ & UFMS \\
\hline $\begin{array}{l}\text { Reflexões sobre a } \\
\text { prática pedagógica } \\
\text { do docente cego no } \\
\text { ensino de química } \\
\text { para alunos cegos. }\end{array}$ & $\begin{array}{c}\text { Deficiência } \\
\text { visual, docente } \\
\text { cego, ensino de } \\
\text { química }\end{array}$ & ES & FP & Visual & $\mathrm{TC}$ & $\begin{array}{l}\text { UFAC, } \\
\text { CAPD } \\
\text { V }\end{array}$ \\
\hline $\begin{array}{l}\text { Uso da Semiótica em } \\
\text { Estratégias Voltadas } \\
\text { para a Educação } \\
\text { Inclusiva Situada no } \\
\text { Ensino de Ciências }\end{array}$ & $\begin{array}{l}\text { Autismo, inclu- } \\
\text { são e semiótica }\end{array}$ & EB & IDP & $\begin{array}{c}\text { Intelec- } \\
\text { tual }\end{array}$ & $\mathrm{TC}$ & UFRJ \\
\hline
\end{tabular}

Fonte: Autoria própria, 2020. 
Quadro B: Publicações avaliadas dos anais digitais disponibilizados pelo XVIII ENEQ (2016)

\begin{tabular}{|c|c|c|c|c|c|c|}
\hline Título & $\begin{array}{c}\text { Palavras- } \\
\text { chave }\end{array}$ & EE & PRD & AI & FA & IE \\
\hline $\begin{array}{l}\text { A construção de conhe- } \\
\text { cimento em química } \\
\text { através do uso de } \\
\text { métodos diferenciados } \\
\text { de ensino para alunos } \\
\text { com síndrome de Down }\end{array}$ & $\begin{array}{l}\text { Ensino de } \\
\text { química, Sín- } \\
\text { drome de } \\
\text { Down, Metodo- } \\
\text { logia de Ensino }\end{array}$ & EB & IDP & Intelectual & $\mathrm{RS}$ & UFES \\
\hline $\begin{array}{c}\text { A educação inclusiva } \\
\text { nas investigações dos } \\
\text { grupos de pesquisa em } \\
\text { educação química no } \\
\text { Brasil }\end{array}$ & $\begin{array}{c}\text { Inclusão, Gru- } \\
\text { pos de Pesquisa, } \\
\text { Educação Quí- } \\
\text { mica }\end{array}$ & ES & FP & - & $\mathrm{TC}$ & $\begin{array}{l}\text { UFFS, } \\
\text { UFPEL }\end{array}$ \\
\hline $\begin{array}{l}\text { A educação química } \\
\text { inclusiva na visão de } \\
\text { professores de uma } \\
\text { escola pública de } \\
\text { Anápolis, Goiás. }\end{array}$ & $\begin{array}{l}\text { Química, Edu- } \\
\text { cação Inclusiva, } \\
\text { Professores }\end{array}$ & EB & FP & - & RS & IFG \\
\hline $\begin{array}{l}\text { A opinião de surdos e } \\
\text { ouvintes sobre o seu } \\
\text { processo de aprendiza- } \\
\text { gem em aulas de quí- } \\
\text { mica: uma análise } \\
\text { proveniente de questio- } \\
\text { nários semiestruturados }\end{array}$ & $\begin{array}{l}\text { Ensino de } \\
\text { Química, Sur- } \\
\text { dez, Inclusão }\end{array}$ & $\mathrm{EB}$ & IDP & Auditiva & $\mathrm{RS}$ & UFJF \\
\hline $\begin{array}{l}\text { A produção de recursos } \\
\text { didáticos para estudan- } \\
\text { tes surdos: possibilida- } \\
\text { des interdisciplinares } \\
\text { no curso de licenciatura } \\
\text { em química - IF catari- } \\
\text { nense /campus Araqua- } \\
\text { ri }\end{array}$ & $\begin{array}{c}\text { Ensino de } \\
\text { Química, } \\
\text { LIBRAS, } \\
\text { Aprendizagem }\end{array}$ & ES & MD & Auditiva & $\mathrm{TC}$ & IFC \\
\hline $\begin{array}{l}\text { A química do café e a } \\
\text { lei 10.639/03: uma } \\
\text { atividade prática de } \\
\text { extração da cafeína a }\end{array}$ & $\begin{array}{l}\text { Cultura africa- } \\
\text { na, Ensino de } \\
\text { Química, Extra- } \\
\text { ção da cafeína, }\end{array}$ & EB & IDP & Racial & $\mathrm{TC}$ & UFG \\
\hline
\end{tabular}




\begin{tabular}{|c|c|c|c|c|c|c|}
\hline $\begin{array}{c}\text { partir de produtos } \\
\text { naturais }\end{array}$ & Lei $10.639 / 03$ & & & & & \\
\hline $\begin{array}{l}\text { A representação imagé- } \\
\text { tica no ensino de quí- } \\
\text { mica para surdos: em } \\
\text { foco os estados físicos } \\
\text { da água. }\end{array}$ & $\begin{array}{l}\text { Surdos, Repre- } \\
\text { sentação Imagé- } \\
\text { tica, Química }\end{array}$ & ES & IDP & Auditiva & RS & $\begin{array}{c}\text { UFG, } \\
\text { IFG, } \\
\text { CNSA, } \\
\text { CEJBM } \\
\text { P }\end{array}$ \\
\hline $\begin{array}{l}\text { A sensibilidade cromá- } \\
\text { tica e a leitura de cores: } \\
\text { a discromatopsia como } \\
\text { um obstáculo para a } \\
\text { aprendizagem }\end{array}$ & $\begin{array}{l}\text { sensibilidade } \\
\text { cromática, } \\
\text { aprendizagem, } \\
\text { ensino de quí- } \\
\text { mica }\end{array}$ & EB & MD & Visual & RS & $\begin{array}{l}\text { PUC- } \\
\text { GO, } \\
\text { UFG }\end{array}$ \\
\hline $\begin{array}{l}\text { Análise crítica de uma } \\
\text { proposta de recurso } \\
\text { didático para a inclusão } \\
\text { de alunos com defici- } \\
\text { ência visual no ensino } \\
\text { de química }\end{array}$ & $\begin{array}{l}\text { ensino de quí- } \\
\text { mica, deficiên- } \\
\text { cia visual, } \\
\text { recurso didático } \\
\text { inclusivo }\end{array}$ & EB & MD & Visual & RS & UnB \\
\hline $\begin{array}{c}\text { Análise da produção de } \\
\text { trabalhos relacionados } \\
\text { com o ensino de ciên- } \\
\text { cias da natureza e suas } \\
\text { tecnologias para alunos } \\
\text { surdos }\end{array}$ & $\begin{array}{l}\text { LIBRAS, quí- } \\
\text { mica, ensino e } \\
\text { aprendizagem }\end{array}$ & ES & LB & Auditiva & $\mathrm{TC}$ & USP \\
\hline $\begin{array}{l}\text { Análise de textos do } \\
\text { ENEQ sobre a educa- } \\
\text { ção inclusiva para } \\
\text { surdos a partir da } \\
\text { perspectiva histórico- } \\
\text { cultural }\end{array}$ & $\begin{array}{l}\text { Educação inclu- } \\
\text { siva, Ensino de } \\
\text { química, Surdos }\end{array}$ & ES & LB & Auditiva & $\mathrm{TC}$ & UFBA \\
\hline $\begin{array}{c}\text { Artefatos pedagógicos } \\
\text { adaptados ao ensino de } \\
\text { química para surdos }\end{array}$ & $\begin{array}{l}\text { Artefatos quí- } \\
\text { micos, ativida- } \\
\text { des inclusivas, } \\
\text { surdez }\end{array}$ & EB & MD & Auditiva & $\mathrm{RS}$ & UFES \\
\hline $\begin{array}{l}\text { As temáticas apresen- } \\
\text { tadas nos estudos com } \\
\text { alunos surdos publica- } \\
\text { dos em anais de even- }\end{array}$ & $\begin{array}{l}\text { ensino de quí- } \\
\text { mica, Libras, } \\
\text { surdos }\end{array}$ & ES & LB & Auditiva & $\mathrm{TC}$ & $\begin{array}{l}\text { UFABC } \\
\text {, UFF }\end{array}$ \\
\hline
\end{tabular}




\begin{tabular}{|c|c|c|c|c|c|c|}
\hline $\begin{array}{l}\text { tos e periódicos da área } \\
\text { de ensino de química } \\
\text { e/ou ciências }\end{array}$ & & & & & & \\
\hline $\begin{array}{l}\text { Áudio-descrição como } \\
\text { estratégia pedagógica } \\
\text { de inclusão no ensino } \\
\text { de química }\end{array}$ & $\begin{array}{l}\text { Áudio- } \\
\text { descrição, } \\
\text { ensino de quí- } \\
\text { mica, inclusão } \\
\text { escolar }\end{array}$ & EB & MD & Visual & $\mathrm{TC}$ & UnB \\
\hline $\begin{array}{l}\text { Comparações entre } \\
\text { imagens e suas áudio- } \\
\text { descrições para defici- } \\
\text { entes visuais em um } \\
\text { livro didático de quími- } \\
\text { ca }\end{array}$ & $\begin{array}{l}\text { Bachelard, } \\
\text { ensino de quí- } \\
\text { mica, cego }\end{array}$ & ES & IDP & Visual & $\mathrm{TC}$ & UFRJ \\
\hline $\begin{array}{l}\text { Confecção de material } \\
\text { didático para a alfabeti- } \\
\text { zação científica de } \\
\text { alunos com deficiência } \\
\text { auditiva }\end{array}$ & $\begin{array}{l}\text { ensino de quí- } \\
\text { mica, LIBRAS, } \\
\text { tabela periódica }\end{array}$ & EB & MD & Auditiva & $\mathrm{TC}$ & USP \\
\hline $\begin{array}{l}\text { Construção de recursos } \\
\text { alternativos para o } \\
\text { ensino de química para } \\
\text { alunos com deficiên- } \\
\text { cias }\end{array}$ & $\begin{array}{l}\text { inclusão, ensino } \\
\text { de química, } \\
\text { recursos alterna- } \\
\text { tivos }\end{array}$ & ES & MD & Múltiplas & $\mathrm{TC}$ & $\begin{array}{l}\text { UNIPA } \\
\text { MPA, } \\
\text { UFPEL, } \\
\text { UnB }\end{array}$ \\
\hline $\begin{array}{l}\text { Desenvolvimento de } \\
\text { uma tabela periódica } \\
\text { utilizando o sistema } \\
\text { Signwritting. }\end{array}$ & $\begin{array}{l}\text { Tabela periódi- } \\
\text { ca, Educação de } \\
\text { surdos, Sig- } \\
\text { nWritting }\end{array}$ & EB & MD & Auditiva & RS & UDESC \\
\hline $\begin{array}{c}\text { Educação de surdos } \\
\text { brasileiros: de Dom } \\
\text { Pedro II aos desafios } \\
\text { atuais }\end{array}$ & $\begin{array}{l}\text { Inclusão, Quí- } \\
\text { mica, Surdos }\end{array}$ & ES & LB & Auditiva & TC & UFSC \\
\hline $\begin{array}{l}\text { Educação inclusiva sob } \\
\text { a ótica de educadores } \\
\text { da rede regular de } \\
\text { Salinas/MG. }\end{array}$ & $\begin{array}{l}\text { inclusão escolar, } \\
\text { formação de } \\
\text { professores } \\
\text { escola pública, } \\
\text { política pública }\end{array}$ & EB & FP & - & TC & IFNMG \\
\hline $\begin{array}{c}\text { Elementos para a } \\
\text { elaboração de uma } \\
\text { estratégia didática para }\end{array}$ & $\begin{array}{c}\text { Ensino de } \\
\text { Química, Raci- } \\
\text { ocínio Qualita- }\end{array}$ & EB & IDP & Auditiva & $\mathrm{TC}$ & $\begin{array}{c}\text { UnB, } \\
\text { IF } \\
\text { Goiano }\end{array}$ \\
\hline
\end{tabular}




\begin{tabular}{|c|}
\hline $\begin{array}{l}\text { o ensino de química, } \\
\text { destinada ao aprendi- } \\
\text { zado de surdos e ouvin- } \\
\text { tes, baseada em racio- } \\
\text { cínio qualitativo }\end{array}$ \\
\hline $\begin{array}{l}\text { Ensino de química e } \\
\text { inclusão: um episódio } \\
\text { da educação de surdos } \\
\text { na rede pública do } \\
\text { munícipio de cabecei- } \\
\text { ras de Goiás }\end{array}$ \\
\hline $\begin{array}{l}\text { Ensino de transforma- } \\
\text { ção química em uma } \\
\text { turma de estudantes } \\
\text { surdos: contextualizan- } \\
\text { do por meio da ferru- } \\
\text { gem }\end{array}$ \\
\hline $\begin{array}{l}\text { Experimentação no } \\
\text { ensino de química com } \\
\text { cegos: uma pesquisa na } \\
\text { formação inicial dos } \\
\text { professores }\end{array}$ \\
\hline $\begin{array}{l}\text { Experimentos de quí- } \\
\text { mica aplicados no i } \\
\text { encontro de surdos com } \\
\text { a ciência: uma reflexão } \\
\text { para a atuação docente }\end{array}$ \\
\hline $\begin{array}{l}\text { Formação de professo- } \\
\text { res de química e educa- } \\
\text { ção inclusiva: análise } \\
\text { dos currículos dos } \\
\text { cursos de licenciatura }\end{array}$ \\
\hline $\begin{array}{l}\text { Formação docente em } \\
\text { química a partir da } \\
\text { experimentação: estu- } \\
\text { dos sobre o uso de } \\
\text { tecnologia assistiva } \\
\text { para deficientes visuais }\end{array}$ \\
\hline $\begin{array}{l}\text { Implementação da lei } \\
\text { 10.639/03: uma ação }\end{array}$ \\
\hline
\end{tabular}

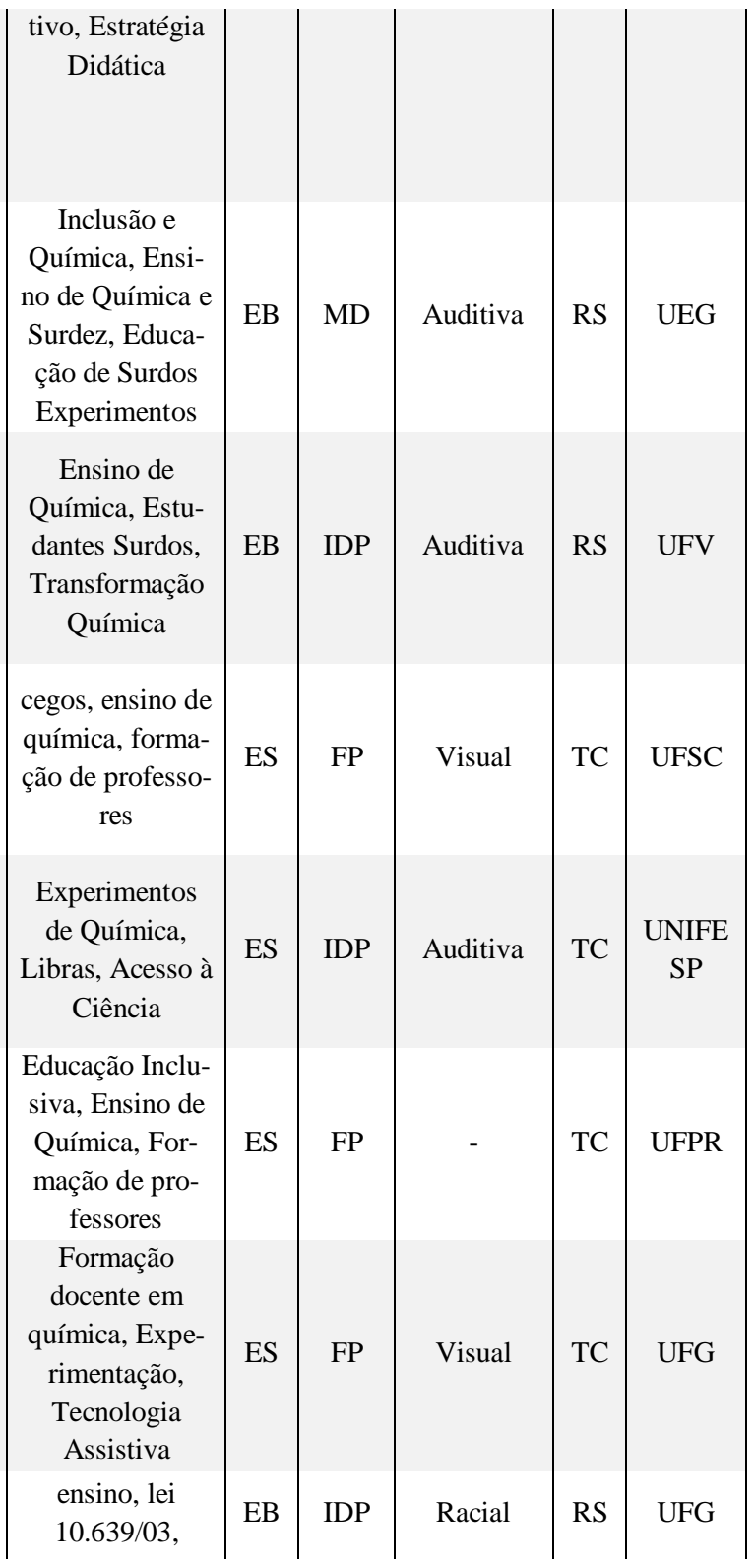




\begin{tabular}{|c|c|c|c|c|c|c|}
\hline $\begin{array}{l}\text { afirmativa a partir do } \\
\text { ensino de química. }\end{array}$ & diáspora & & & & & \\
\hline $\begin{array}{l}\text { Implementação da lei } \\
\text { 10639/03 no ensino de } \\
\text { química: uma experi- } \\
\text { ência no contexto da } \\
\text { produção de biocom- } \\
\text { bustíveis e o aqueci- } \\
\text { mento global }\end{array}$ & $\begin{array}{l}\text { Aquecimento } \\
\text { Global, Lei } \\
\text { 10639/03, orixá }\end{array}$ & EB & IDP & Racial & $\mathrm{TC}$ & UFG \\
\hline $\begin{array}{c}\text { Inclusão de alunos } \\
\text { autistas: adaptação de } \\
\text { plano de aula de quími- } \\
\text { ca }\end{array}$ & $\begin{array}{l}\text { inclusão, autis- } \\
\text { mo, aula de } \\
\text { química }\end{array}$ & EB & IDP & Intelectual & $\mathrm{RS}$ & UEPG \\
\hline $\begin{array}{l}\text { Inclusão no ensino } \\
\text { superior: um estudo } \\
\text { com docentes de um } \\
\text { curso de licenciatura } \\
\text { em química }\end{array}$ & $\begin{array}{l}\text { Educação Inclu- } \\
\text { siva, Formação } \\
\text { docente, Inclu- } \\
\text { são }\end{array}$ & ES & FP & - & $\mathrm{TC}$ & UnB \\
\hline $\begin{array}{l}\text { Intervenção pedagógi- } \\
\text { ca: sexualidade e iden- } \\
\text { tidade de gênero na } \\
\text { formação inicial de } \\
\text { professores de química. }\end{array}$ & $\begin{array}{l}\text { Gênero, Sexua- } \\
\text { lidade, Didática }\end{array}$ & ES & IDP & $\begin{array}{c}\text { Gênero e } \\
\text { sexualida- } \\
\text { de }\end{array}$ & $\mathrm{TC}$ & UFG \\
\hline $\begin{array}{l}\text { Intervenções do PIBID } \\
\text { na construção do ensi- } \\
\text { no aprendizagem de } \\
\text { química na educação } \\
\text { especial }\end{array}$ & $\begin{array}{l}\text { APAE, Educa- } \\
\text { ção Especial, } \\
\text { PIBID }\end{array}$ & ES & IDP & Intelectual & $\mathrm{RS}$ & IFC \\
\hline $\begin{array}{l}\text { Investigação sobre } \\
\text { ensino de cromatogra- } \\
\text { fia para alunos com } \\
\text { deficiência visual: } \\
\text { perspectivas de profes- } \\
\text { sores e proposta de } \\
\text { atividade didática }\end{array}$ & $\begin{array}{c}\text { Educação Inclu- } \\
\text { siva, Deficiên- } \\
\text { cia Visual, } \\
\text { Ensino de } \\
\text { Química }\end{array}$ & ES & IDP & Visual & $\mathrm{TC}$ & IFES \\
\hline $\begin{array}{l}\text { Leite adulterado: uma } \\
\text { proposta investigativa } \\
\text { vivenciada por estudan- } \\
\text { tes surdos na perspecti- } \\
\text { va bilíngue }\end{array}$ & $\begin{array}{l}\text { ensino de quí- } \\
\text { mica, surdo, SEI }\end{array}$ & EB & IDP & Auditiva & RS & $\begin{array}{l}\text { SELI, } \\
\text { IFSP }\end{array}$ \\
\hline
\end{tabular}




\begin{tabular}{|c|c|c|c|c|c|c|}
\hline $\begin{array}{l}\text { Materiais de suporte no } \\
\text { ensino de química para } \\
\text { surdos? }\end{array}$ & $\begin{array}{l}\text { Materiais Didá- } \\
\text { ticos, Surdos, } \\
\text { Química }\end{array}$ & ES & LB & Auditiva & $\mathrm{TC}$ & UFU \\
\hline $\begin{array}{l}\text { O café no dia a dia, } \\
\text { propriedades químicas } \\
\text { e sua relação Brasil- } \\
\text { África. }\end{array}$ & $\begin{array}{l}\text { Café, Lei } \\
\text { 10.639, Ensino } \\
\text { de Química }\end{array}$ & EB & IDP & Racial & $\mathrm{TC}$ & UFRN \\
\hline $\begin{array}{l}\text { O ensino de química } \\
\text { em libras: interpretando } \\
\text { interações }\end{array}$ & $\begin{array}{l}\text { Sinais, media- } \\
\text { ção, interações }\end{array}$ & ES & IDP & Auditiva & $\mathrm{RS}$ & UFMT \\
\hline $\begin{array}{l}\text { O ensino de química no } \\
\text { contexto dos alunos } \\
\text { com altas habilida- } \\
\text { des/superdotação } \\
\text { (AH/SD). }\end{array}$ & $\begin{array}{c}\text { Ensino de } \\
\text { química, Altas } \\
\text { Habilida- } \\
\text { des/Superdotaçã } \\
\text { o, Educação } \\
\text { especial }\end{array}$ & EB & FP & Intelectual & $\mathrm{TC}$ & $\begin{array}{l}\text { UCB, } \\
\text { IF } \\
\text { Goiano }\end{array}$ \\
\hline $\begin{array}{l}\text { O ensino de química } \\
\text { para alunos surdos: } \\
\text { conceito de misturas no } \\
\text { ensino de ciências }\end{array}$ & $\begin{array}{l}\text { conceitos quí- } \\
\text { micos, educação } \\
\text { de surdos, } \\
\text { ensino de ciên- } \\
\text { cias }\end{array}$ & EB & IDP & Auditiva & $\mathrm{TC}$ & UFG \\
\hline $\begin{array}{l}\text { O ensino de química } \\
\text { para surdos em Anápo- } \\
\text { lis, Goiás: uma análise } \\
\text { a partir da triangulação } \\
\text { de dados }\end{array}$ & $\begin{array}{l}\text { Ensino de } \\
\text { Química, Alu- } \\
\text { nos Surdos, } \\
\text { Triangulação }\end{array}$ & ES & LB & Auditiva & $\mathrm{TC}$ & IFG \\
\hline $\begin{array}{c}\text { O estudo da educação } \\
\text { inclusiva na formação } \\
\text { de professores de } \\
\text { química }\end{array}$ & $\begin{array}{c}\text { Ensino de } \\
\text { Química, Edu- } \\
\text { cação Inclusiva, } \\
\text { Pessoa com } \\
\text { Deficiência }\end{array}$ & ES & LB & Auditiva & $\mathrm{TC}$ & IFMS \\
\hline $\begin{array}{l}\text { Os caminhos da educa- } \\
\text { ção inclusiva para o } \\
\text { ensino de química: uma } \\
\text { análise dos anais dos } \\
\text { encontros nacionais de } \\
\text { ensino de química, de } \\
2008 \text { a } 2014\end{array}$ & $\begin{array}{l}\text { Educação Inclu- } \\
\text { siva, Produção } \\
\text { acadêmica, } \\
\text { ENEQ }\end{array}$ & ES & LB & - & $\mathrm{TC}$ & UFPR \\
\hline $\begin{array}{l}\text { Os materiais didáticos } \\
\text { adaptados para defici- }\end{array}$ & $\begin{array}{c}\text { Ensino de } \\
\text { Química, Defi- }\end{array}$ & EB & MD & Visual & TC & UFPR \\
\hline
\end{tabular}




\begin{tabular}{|c|c|c|c|c|c|c|}
\hline $\begin{array}{l}\text { entes visuais nas aulas } \\
\text { de química na perspec- } \\
\text { tiva de alunos cegos, } \\
\text { especialista e gestor } \\
\text { educacional }\end{array}$ & $\begin{array}{l}\text { ciência Visual, } \\
\text { Material Didáti- } \\
\text { co }\end{array}$ & & & & & \\
\hline $\begin{array}{l}\text { PIBID: a experimenta- } \\
\text { ção no ensino de quí- } \\
\text { mica para surdos }\end{array}$ & $\begin{array}{l}\text { PIBID, Experi- } \\
\text { mentação, } \\
\text { Surdez. }\end{array}$ & ES & IDP & Auditiva & $\mathrm{TC}$ & $\begin{array}{l}\text { UFG, } \\
\text { IFG, } \\
\text { CNSA, } \\
\text { CEJBM } \\
\text { P }\end{array}$ \\
\hline $\begin{array}{c}\text { Química experimental } \\
\text { e a lei 10639/03: inser- } \\
\text { ção da história e cultura } \\
\text { da África e afro- } \\
\text { brasileira no ensino de } \\
\text { química }\end{array}$ & $\begin{array}{c}\text { Descolonização, } \\
\text { do Currículo, } \\
\text { Lei 10639/03 }\end{array}$ & ES & IDP & Racial & $\mathrm{TC}$ & UFG \\
\hline $\begin{array}{l}\text { Recursos acessíveis ao } \\
\text { ensino de química: } \\
\text { diagrama tátil de Linus } \\
\text { Pauling e tabela perió- } \\
\text { dica }\end{array}$ & $\begin{array}{l}\text { alunos com } \\
\text { deficiência, } \\
\text { adaptação de } \\
\text { recursos, ensino } \\
\text { de química }\end{array}$ & EB & MD & Visual & RS & $\begin{array}{c}\text { UNIPA } \\
\text { MPA }\end{array}$ \\
\hline $\begin{array}{c}\text { Sobre mulheres e } \\
\text { produção em ciências: } \\
\text { discutindo questões de } \\
\text { gênero em aulas de } \\
\text { química }\end{array}$ & $\begin{array}{l}\text { Mulheres na } \\
\text { Ciência, Aulas } \\
\text { de Química, } \\
\text { Equidade de } \\
\text { Gênero }\end{array}$ & EB & IDP & $\begin{array}{l}\text { Gênero e } \\
\text { sexualida- } \\
\text { de }\end{array}$ & RS & UFG \\
\hline $\begin{array}{l}\text { Sobre o apartheid e a } \\
\text { platina: uma experiên- } \\
\text { cia na implementação } \\
\text { da lei } 10.639 / 03 \text { no } \\
\text { currículo da química }\end{array}$ & $\begin{array}{l}\text { Currículo, } \\
\text { Platina, Ensino } \\
\text { de química }\end{array}$ & ES & IDP & Racial & $\mathrm{TC}$ & UFG \\
\hline $\begin{array}{l}\text { Tendências atuais da } \\
\text { pesquisa em ensino de } \\
\text { história e cultura afro- } \\
\text { brasileira no ensino de } \\
\text { química }\end{array}$ & $\begin{array}{c}\text { estado da arte, } \\
\text { Lei 10639/03, } \\
\text { Química }\end{array}$ & ES & LB & Racial & $\mathrm{TC}$ & $\begin{array}{c}\text { IF } \\
\text { Goiano, } \\
\text { UFU, } \\
\text { CBM, } \\
\text { URI }\end{array}$ \\
\hline $\begin{array}{l}\text { Tendências das pesqui- } \\
\text { sas internacionais sobre } \\
\text { o ensino de ciências } \\
\text { para deficientes visu- }\end{array}$ & $\begin{array}{c}\text { Deficiência } \\
\text { visual, Educa- } \\
\text { ção inclusiva, } \\
\text { Material Didáti- }\end{array}$ & ES & LB & Visual & $\mathrm{TC}$ & UFPR \\
\hline
\end{tabular}


ais: foco nos materiais

didáticos para o ensino

de química.

co

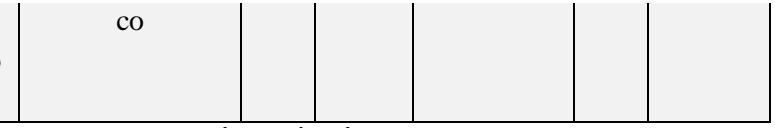

Fonte: Autoria própria, 2020.

Quadro C: Publicações avaliadas dos anais digitais disponibilizados pelo XIX ENEQ (2018)

\begin{tabular}{|c|c|c|c|c|c|c|}
\hline Título & $\begin{array}{c}\text { Palavras- } \\
\text { chave }\end{array}$ & EE & PRD & AI & FA & IE \\
\hline $\begin{array}{l}\text { O homem trans e a química: } \\
\text { Análise do potencial das } \\
\text { situações que atravessam } \\
\text { esses sujeitos e suas experi- } \\
\text { ências, para a abordagem de } \\
\text { questões de gênero e sexuali- } \\
\text { dade no ensino de química }\end{array}$ & $\begin{array}{l}\text { Educação } \\
\text { sexual, } \\
\text { Estudos de } \\
\text { gênero; } \\
\text { Química da } \\
\text { sexualidade. }\end{array}$ & - & AP & $\begin{array}{l}\text { Gênero e } \\
\text { sexuali- } \\
\text { dade }\end{array}$ & RS & UFAC \\
\hline $\begin{array}{l}\text { Perfil da representatividade } \\
\text { de gênero em disciplinas de } \\
\text { físico-química }\end{array}$ & $\begin{array}{l}\text { Representa- } \\
\text { tividade, } \\
\text { Gênero, } \\
\text { Disciplinas }\end{array}$ & ES & AP & $\begin{array}{l}\text { Gênero e } \\
\text { sexuali- } \\
\text { dade }\end{array}$ & RS & UFRJ \\
\hline $\begin{array}{l}\text { Aula contextualizada e o uso } \\
\text { das Tecnologias da Informa- } \\
\text { ção e Comunicação (TICs) } \\
\text { para alunos neurotípicos e } \\
\text { com síndrome de Down de } \\
\text { um curso técnico em controle } \\
\text { ambiental }\end{array}$ & $\begin{array}{l}\text { Síndrome } \\
\text { de Down, } \\
\text { Reciclagem. }\end{array}$ & EB & IDP & $\begin{array}{l}\text { Intelectu- } \\
\text { al }\end{array}$ & RS & IFPB \\
\hline $\begin{array}{l}\text { Acerca do papel da mídia e } \\
\text { proteção da pele negra em } \\
\text { aulas de química }\end{array}$ & $\begin{array}{l}\text { Ensino de } \\
\text { Química, } \\
\text { Proteção de } \\
\text { pele }\end{array}$ & EB & IDP & Racial & RS & UFG \\
\hline $\begin{array}{l}\text { Oficinas de ciências inclusi- } \\
\text { vas: um diferencial na forma- } \\
\text { ção do professor de química. }\end{array}$ & $\begin{array}{l}\text { Educação, } \\
\text { Inclusão, } \\
\text { formação }\end{array}$ & ES & FP & $\begin{array}{l}\text { Intelectu- } \\
\text { al }\end{array}$ & RS & USP \\
\hline $\begin{array}{l}\text { A rede de apoio à educação } \\
\text { inclusiva em Jataí-GO: limi- } \\
\text { tes e possibilidades }\end{array}$ & $\begin{array}{l}\text { Educação } \\
\text { Especial; } \\
\text { Educação } \\
\text { Inclusiva; }\end{array}$ & EB & FP & - & RS & UFG \\
\hline
\end{tabular}




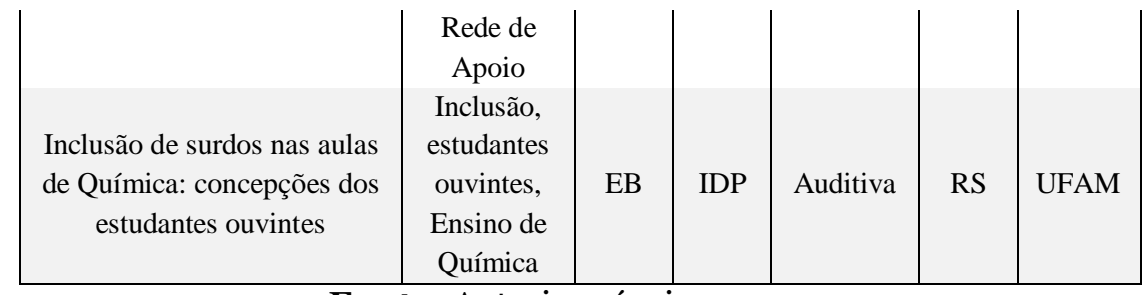

Fonte: Autoria própria, 2020. 